\title{
LONG TERM FOLLOW-UP IN A PATIENT WITH PAPILLARY GLIONEURONAL TUMOR
}

\author{
Guilherme Borges', Leonardo Bonilha', \\ Ana Silvia Menezes², Luciano de Souza Queiroz², \\ Edmur Franco Carelli', Veronica Zanardi ${ }^{3}$, Jose Ribeiro Menezes ${ }^{3}$
}

\begin{abstract}
We report a case of a young female patient with a rare and recently described form of brain tumor. This patient had a history of headache, hemiparesis and motor simple partial seizures. Her investigation revealed a brain tumor involving the left frontal and parietal lobes. The radiological images showed a cystic mass with multiple nodular masses and a rim of contrast enhancement extending from the right parietal cortex to the ipsilateral ventricle and corpus callosum. The patient underwent gross resection of the lesion and the histological analysis of the surgical specimen revealed a pseudopapillary structure formed by delicate vessels intermixed with a fibrillary pattern and bordered by intense astrocytic reaction with Rosenthal fibers. These features correspond to the recently described mixed neuronal-glial neoplasm, the papillary glioneuronal tumor. The patient has been followed for five years since the surgical treatment, without evidence of tumor recurrence, confirming the indolent behavior of this type of tumor.
\end{abstract}

KEY WORDS: papillary glioneuronal tumor, mixed glioneuronal tumor, brain tumor, glioma.

\section{Seguimento tardio de paciente com tumor papilar glioneuronal}

RESUMO - Relatamos o caso de uma jovem paciente com um tumor cerebral raro e recentemente descrito. Essa paciente apresentou-se com queixas de cefaléia, hemiparesia e crises epiléticas parciais simples. Sua investigação revelou um tumor cerebral envolvendo os lobos frontal e parietal esquerdos. As imagens radiológicas mostraram uma massa cística com massas nodulares múltiplas e reforço anelar de contraste estendendo do córtex parietal direito aos ventrículo lateral e corpo caloso ipsilaterais. A paciente se submeteu à ressecção do tumor e a análise histológica da lesão revelou uma estrutura pseudopapilar formada por vasos delicados entremeados com um padrão fibrilar e emoldurada por intensa reação astrocítica com fibras de Rosenthal. Essas características correspondem a uma forma de neoplasia mista glial-neuronal recentemente descrita, o tumor papilar glioneuronal. A paciente está em seguimento desde a cirurgia sem evidência de recorrência tumoral, confirmando o comportamento benigno desse tipo de tumor

PALAVRAS-CHAVE: tumor papilar glioneuronal, tumor misto glioneuronal, tumor cerebral, glioma.

Mixed glioneuronal tumors form a heterogeneous group. A great number of histological forms have been described and the WHO classification includes among neuronal and mixed neuronalglial neoplasm the following tumors: gangliocytoma, dysembryoplastic neuroepithelial tumor (DNT), ganglioglioma, anaplastic ganglioglioma and central neurocytoma'. In 1998, a new variant of mixed glioneuronal tumor was described. Komori et al. reported 9 cases of an extraventricular tumor of indolent behavior composed primarily of glioneuronal elements with prominent pseudopapillary structures ${ }^{2}$. Somewhat distinct from other variants previously described, this unusual mixed glio- neuronal tumor of the central nervous system was called papillary glioneuronal tumor (PGNT). The new entity was characterized by two distinct morphologic components: 1) a compact pseudopapillae composed of hyalinized vessels covered by a single layer of glial fibrillary acid protein (GFAP)-positive astrocytes; and 2) synaptophysin-positive neuronal cells of varying size, like neurocytes, ganglioid cells and ganglion cells within neuropil2. The first report of this new pathological entity was published in 1998, comprising nine very similar cases of periventricular cystic intracranial lesions ${ }^{2}$ and after that, other two cases have been described ${ }^{3,4}$.

In this present article we present a case of a 14

State University of Campinas - (UNICAMP), Campinas SP, Brazil: ${ }^{1}$ Neurology and Neurosurgery Department; ${ }^{2}$ Pathology Department; ${ }^{3}$ Radiology Department.

Received 9 January 2004, received in final form 23 April 2004. Accepted 9 June 2004.

Dr. Guilherme Borges - Rua Visconde do Rio Claro 322 - 13083-650 Campinas SP - Brasil. E-mail: guiborges@fcm.unicamp.br 
year-old patient with a cystic extraventricular neoplasm who was submitted to surgical treatment. Analysis of the pathological specimen excised was consistent with the diagnosis of PGNT. Our case report was approved by the Ethical Committee of our Medical School.

\section{CASE}

Clinical presentation - A fourteen year-old female patient was admitted for medical evaluation in September, 1997 due to an 18 month history of headache associated with a mild decrease in muscle strength in her left arm and leg. Focal brief motor seizures involving her left arm were present in the time of the onset of the hemi-

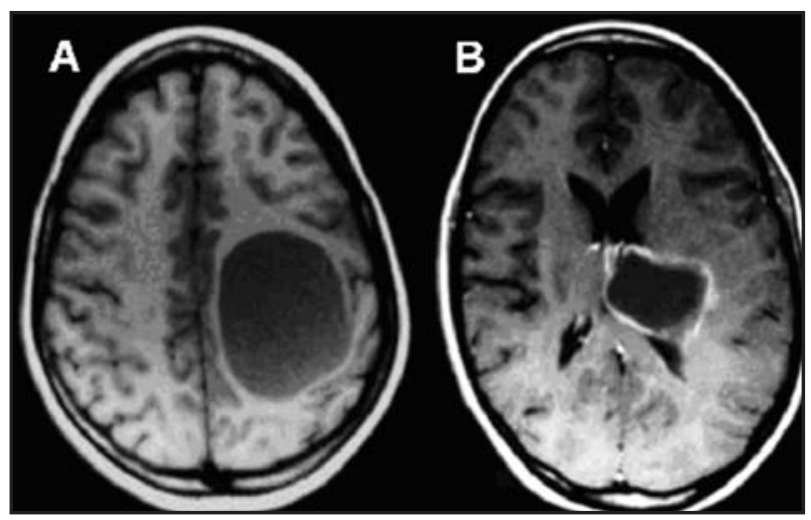

Fig 1. A) T1-weighted MRI axial image without contrast showing a large left cystic parietal lesion. B) T1-weighted MRI axial image showing rim contrast enhancement. paresis were totally controlled with antiepileptic drugs. During her physical examination she was found to be awake and alert and only a mild left side hemiparesis was noticeable. She underwent further investigation and a magnetic resonance imaging (MRI) (Fig 1) showed a large cystic lesion in the left frontal and parietal lobes extending from the parietal subcortical area to the ipsilateral ventricle and corpus callosum. The tumor had approximately 5.5 cubic centimeters and was surrounded by a thin wall, with delicate intra-cystic trabeculae. There was intense paramagnetic contrast enhancement of the tumor wall. The tumor also exerted mass-effect displacing the thalamus downward.

The patient underwent gross total resection of the tumor. Frozen-section analysis was inconclusive, and there was suspicious of pylocitic astrocitoma or ependymoma.

Eight days after the surgery the patient was discharged home, without additional neurological deficits. She has been followed ever since in our outpatient clinic, with a mild left side weakness. Two MRI and a CT scan performed up to 56 months after the surgical treatment did not show signs of tumor recurrence.

Histological analysis - A specimen of subcortical brain parenchyma infiltrated by a mildly cellular neoplasia was analyzed. It presented a pseudopapillary structure formed by delicate small vessels, some of them with a hyaline wall surrounded by a single layer of uniform, cuboid, small cells with oval-shaped nuclei with finely granular chromatin and scanty cytoplasm. The pseudopapillae were intermixed with a fibrillary background and rare polygonal large cells with abundant cytoplasm

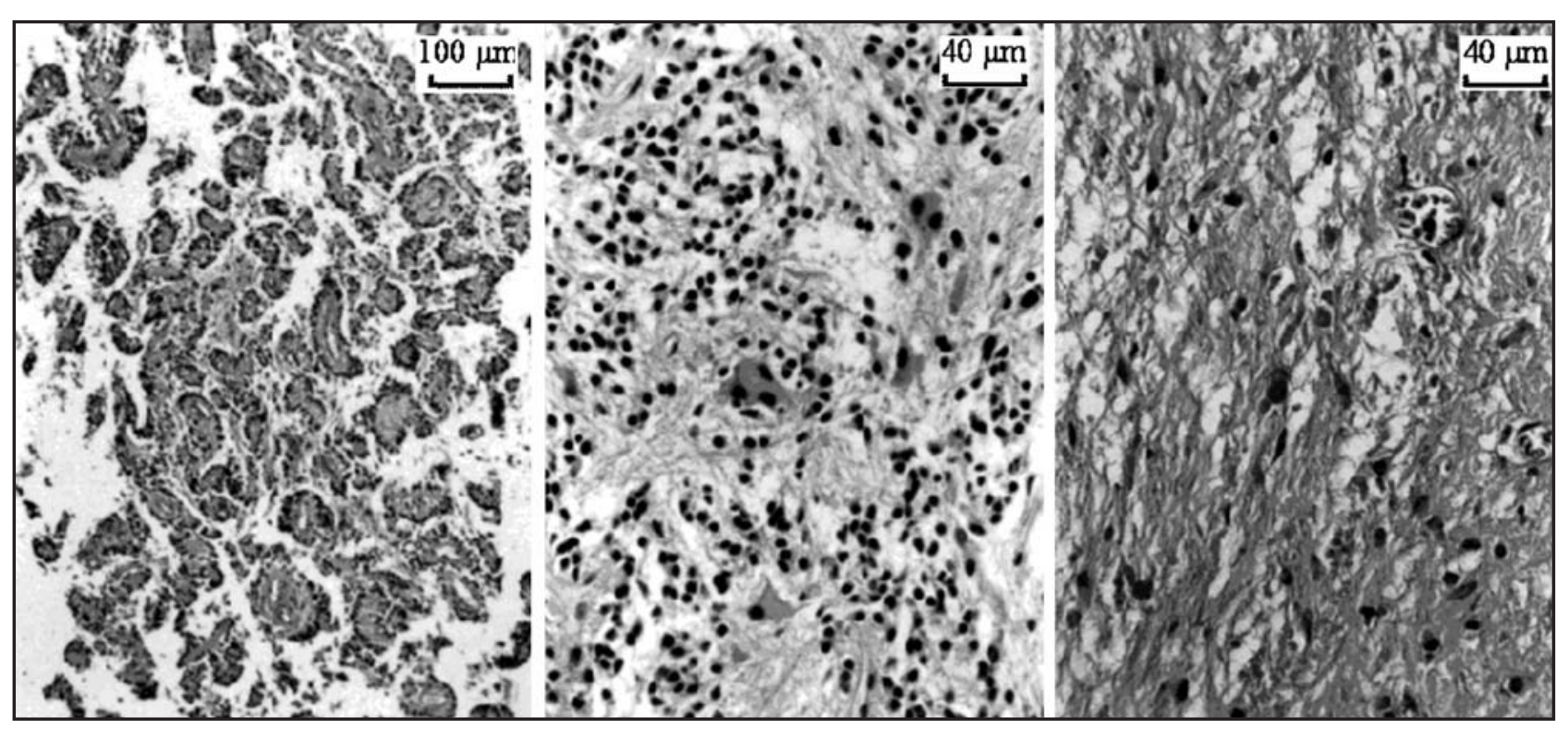

Fig 2. A) Histological section of the surgical specimen showing the pseudo-papillary pattern of the PGNT. B) Histological section of the surgical specimen showing large cells with abundant cytoplasm. This corresponds to the neural element of the neoplasm. C) Histological section of the surgical specimen showing reaction gliosis with Rosenthal fibers. 
and prominent nucleolus. In the borders of the lesion there was intense astrocytic proliferation with conspicuous Rosenthal fibers (Fig 2). The cells that delineated the pseudo-rosettes were immunoreactive with antiglial fibrillary acidic protein and vimentin. The small population of large cells reacted to anti-neuron-specific anti-synaptophysin and TUJ1 (class III beta-tubulin) antibodies. The cytoarchitecture and immune analysis observed corresponds to the pathological entity described in 1998 defined as called papillary glioneuronal tumor (PGNT).

\section{DISCUSSION}

The papillary glioneuronal tumor is a low grade neoplasm distinct from previously described variants of mixed glioneuronal tumors because of the evident pseudopapillary architecture and the unique clinical and radiographic features. It was first described in 1998 in a report of nine very similar cases of periventricular cystic intracranial masses ${ }^{2}$. Two other reports have followed the original description and overall 11 cases of PGNT have been described ${ }^{3,4}$.

The papillary glioneuronal tumor involves white and gray matter and shows both astrocytic and extensive neuronal differentiation, including neurocytes, ganglioid and ganglion cells ${ }^{1}$. All but one case described $^{2-4}$ affected young adults and clinical behavior is probably indolent, as supposed by the extent of mature cells and by one report of long follow-up ${ }^{3}$.

The preferential location involves the cortical and subcortical portions of the temporal lobe, followed by the frontal, parietal and the occipital lobes. Radiological images have showed large periventricular neoplasms marked by a peripheral homogeneous or heterogeneous rim of contrast enhancement. Overall the lesions were round or ovoid in shape and the majority had a large cystic component. Peri-lesional edema was either mild or absent. The tumors had an average of approximately 4 to $5 \mathrm{~cm}$ and were highly vascularizated. The solid components in magnetic resonance studies were isointense in T1-weighted images and iso to hyperintense in T2-weighted images. Calcification was detected in 4 cases.

The histological analysis reveals distinct neuronal and glial conspicuous histological populations. Glial elements were astrocytes, whereas neuronal cells were neurocytes, ganglioid or ganglion cells, showing a spectrum of maturation. A very prominent feature was the presence of highly hyalinized vessels unsheathed by a single or pseudostratified layer of small cubical cells producing a distinct pseudopapillary aspect. These cells, the so-called pseudopapillary component, were regular in size and shape, had eosinophilic cytoplasm and round nuclei. They were strongly immunoreactive for GFAP and S-100 protein. Stains for synaptophysin, class III beta-tubulin, NSE and NFP were negative. Hyalines vessels may be seen in some others glioneuronal tumors ${ }^{5-8}$. However it is the architectural arrangement the most distinctive feature associated with the dual glial-neuronal component.

The neuronal element is composed by large, small or intermediate cells intermixed in a fibrillary matrix. Large ganglionic cells presented with prominent central nucleolus, large cytoplasm with well developed silver stain and argyrophilic process on Bielschowsky silver stain. Small neurocytic cells had small cytoplasm, dark nuclei and none argyrophilic process. Intermediate ganglionic cells possessed intermediate amount of cytoplasm and smaller nuclei. Intermixed in loose or compact manner, the "neuronal component" can be associated with a geometric capillary network resembling an oligodendroglioma ${ }^{3}$. In fact, according to the most prominent neuronal cell lineage present, the PGNT bears resemblance with the neuronal tumor in which each of the neuronal cells is more frequent, ranging in appearance from neurocytomas to gangliocytoma. The broad spectrum of PGNT neuronal differentiation is unique because it involves three different stages of neuronal cell maturation. These features are observed in immunophenotype studies which demonstrate staining for class III beta-tubulin, synaptophysin and neurofilament protein ${ }^{9-12}$.

The advanced maturation of cellular components of PGNT is in concordance with its indolent behavior. Moreover, the PGNT shares good prognostic features with other neuronal or mixed neuroglial tumors such as DNT, neurocytoma and gangliocytoma. This can be observed by the much older age of onset of these tumors when compared to non-differentiated malignant neoplasms such as PNET or central neuroblastoma ${ }^{13,14}$.

The periventricular location of the majority of cases of PGNT suggests its possible origin from the germinative zone in the subependymal plate ${ }^{2}$. The presence of identical nuclei and dense bodies in all cell subtypes within the tumor ${ }^{3}$ are also indicative of a possible common neuroglial progenitor cell. In adult mammals, ependymal cells are derived 
from neural stem cells ${ }^{15,16}$ which can generate the major types of CNS mature cells: neurons, astrocytes and oligodendrocytes ${ }^{17}$. Neoplastic transformation of these cells may account for the formation of glioneuronal tumors, such as the PGNT.

Finally we provide additional evidence for the peculiar histological and neuroimaging patterns of the PGNT. We further highlight the indolent behavior and the benign course of the PGNT.

Acknowledgements - We are deeply grateful to the patient for her kind acceptance to publish her case.

\section{REFERENCES}

1. Kleihues P, Louis DN, Scheithauer BW, et al. The WHO classification of tumors of the nervous system. J Neuropathol Exp Neurol 2002;61:215225.

2. Komori T, Scheithauer BW, Anthony DC, et al. Papillary glioneuronal tumor: a new variant of mixed neuronal-glial neoplasm. Am J Surg Pathol 1998:22:1171-1183.

3. Bouvier-Labit C, Daniel L, Dufour H, Grisoli F, Figarella-Branger D. Papillary glioneuronal tumour: clinicopathological and biochemical study of one case with 7-year follow up. Acta Neuropathol (Berl) 2000;99:321-326.

4. Prayson RA. Papillary glioneuronal tumor. Arch Pathol Lab Med 2000;124:1820-1823.

5. Giangaspero F, Cenacchi G, Losi L, Cerasoli S, Bisceglia M, Burger PC. Extraventricular neoplasms with neurocytoma features: a clinicopathological study of 11 cases. Am J Surg Pathol 1997;21:206-212.
6. Daumas-Duport C. Dysembryoplastic neuroepithelial tumours. Brain Pathol 1993;3:283-295.

7. Hirose T, Schneithauer BW, Lopes MB, Gerber HA, Altermatt HJ, VandenBerg SR. Ganglioglioma: an ultrastructural and immunohistochemical study. Cancer 1997;79:989-1003.

8. Robbins P, Segal A, Narula S, et al. Central neurocytoma. A clinicopathological, immunohistochemical and ultrastructural study of 7 cases. Pathol Res Pract 1995;191:100-111.

9. Lee MK, Rebhun LI, Frankfurter A. Posttranslational modification of class III beta-tubulin. Proc Natl Acad Sci U S A 1990;87:7195-7199.

10. Wiedenmann B, Franke WW, Kuhn C, Moll R, Gould VE. Synaptophysin: a marker protein for neuroendocrine cells and neoplasms. Proc Natl Acad Sci U S A 1986;83:3500-3504.

11. Wiedenmann B, Franke WW. Identification and localization of 0synaptophysin, an integral membrane glycoprotein of $\mathrm{Mr} 38,000$ characteristic of presynaptic vesicles. Cell 1985;41:1017-1028.

12. Miller DC, Koslow M, Budzilovich GN, Burstein DE. Synaptophysin: a sensitive and specific marker for ganglion cells in central nervous system neoplasms. Hum Pathol 1990;21:271-276.

13. Janss AJ, Yachnis AT, Silber JH, et al. Glial differentiation predicts poor clinical outcome in primitive neuroectodermal brain tumors. Ann Neurol 1996;39:481-489.

14. Molenaar WM, Jansson DS, Gould VE, et al. Molecular markers of primitive neuroectodermal tumors and other pediatric central nervous system tumors: monoclonal antibodies to neuronal and glial antigens distinguish subsets of primitive neuroectodermal tumors. Lab Invest 1989;61:635-643

15. Johansson CB, Momma S, Clarke DL, Risling M, Lendahl U, Frisen J. Identification of a neural stem cell in the adult mammalian central nervous system. Cell 1999;96:25-34.

16. von Deimling A, Kleihues P, Saremaslani P, et al. Histogenesis and differentiation potential of central neurocytomas. Lab Invest 1991;64:585-591.

17. Reynolds BA, Weiss S. Clonal and population analyses demonstrate that an EGF-responsive mammalian embryonic CNS precursor is a stem cell. Dev Biol 1996;175:1-13. 